\title{
IDENTIFICATION AND DISTRIBUTION OF SUGARCANE STEM BORER IN BANGLADESH
}

\author{
Md. Ataur Rahman ${ }^{1}$, Md. Shibly Noman ${ }^{2}$, Md. Abdul Maleque ${ }^{2 *}$ \\ Md. Zinnatul Alam ${ }^{3}$, Sultana Afroz ${ }^{4}$ and M.K.A. Chowdhury ${ }^{2}$ \\ Bangladesh Sugarcane Research Institute, Ishurdi, Pabna, Bangladesh
}

\begin{abstract}
Field surveys were conducted during the cropping season of 2010-2011 to assess the distribution of Sugarcane stem borer species in 12 AEZs of Bangladesh. These surveys documented abundance and their distribution and results clearly showed the existence of the stem borer at all locations surveyed, but with a higher incidence in the Atwary (36\%) and initiation of infestation was observed on 20 May. Stem borer incidence and distribution varied significantly among the different locations. Second highest rate of infestation (32\%) was recorded in Bashudebpur followed by Dinajpur (31\%), Pabna and Akandabaria farm (30\%). The lower infestation was recorded in Kaliganj. The percentage of stems attacked at the Kaliganj has never exceeded $23 \%$ followed by Rajshahi (28\%), Thakurgaon and Faridpur (29\%). The rate of infestation of stem borer (Chilo tumidicostalis) in different locations varied from 23-36\%. While morphological characteristics of stem borer species were identified with standard keys and species composition was only predominated by Chilo tumidicostalis Hampson, though previous workers found other borers in addition to this species. The sex ratio of adult moth Chilo tumidicostalis was 1:1.42 after emergence from the reared collected pupae from different locations.
\end{abstract}

Key words: Alternate host, Caterpillar growth stage, Moths, Pupae, Lepidopteran pest, Sugarcane.

\section{INTRODUCTION}

Sugarcane (Saccharum officinarum L.), a perennial tropical crop with a high selftolerant nature, is grown for sugar stored in its stem and propagated through stem cuttings. Sugarcane is grown around the world between tropical and sub-tropical

\footnotetext{
*Corresponding author email: maleq68@yahoo.com

${ }^{1}$ Bangladesh Sugarcane Research Institute, Ishurdi, Pabna, Bangladesh

${ }^{2}$ Crops Division, Bangladesh Agricultural Research Council, Farmgate, Dhaka 1215, Bangladesh

${ }^{3}$ Department of Entomology, Bangabandhu Sheikh Mujibur Rahman Agricultural University,

Gazipur 1706, Bangladesh

${ }^{4}$ Department of Agriculture Extension, Ministry of Agriculture, Dhaka 1000, Bangladesh
}

Received: 28.04.2013 
climate (North latitude $=35^{\circ} \mathrm{C}$ and South latitude $=35^{\circ} \mathrm{C}$ ). Sugarcane is cultivated in more than 100 countries of the tropical and sub-tropical regions of the world (Humbert, 1968). Around $70 \%$ of the world's sugar is produced from this crop (Chowdhury and Vasil, 1993). Sugarcane is cultivated on an area of about 0.16 million hectare of land which almost $50 \%$ area is located in the sugar mills zone, and the remaining $50 \%$ is grown in the non-mills zone, where sugarcane is mostly diverted for jaggary and juice production. Presently, 15 sugar mills are in operation under Bangladesh Sugar and Food Industries Corporation (BSFIC) with a capacity of 0.21 million tons of sugar production per year (BSFIC, 2008).

Stem borer, Chilo tumidicostalis Hampson is a serious insect pest of sugarcane in Bangladesh (Karim and Islam, 1977), Thailand (Suasa-ard et al., 2000), Nepal, Burma (Williams et al., 1969) and Australia (Sallam, 2006). Incidence of stem borer infestation starts from the end of April and continues up to November. However, it remains most abundant from June to September. Hundred percent crop losses by stem borer infestation were recorded in Setabgonj Sugar Mills in Bangladesh during 19731974 cropping season when attack reached as high as $100 \%$ due to the stem borer infestation (Karim and Islam, 1977). In India, it caused 8.2-12.6\% yield loss sometimes reaching up to $70 \%$ with $10.75-48.55 \%$ sugar recovery in endemic areas (Khanna et al., 1957; Butani, 1961). Gupta and Avasthey (1960) also reported 25$70 \%$ and $12-60 \%$ in cane yield due to primary and secondary infestation, respectively in different sugarcane varieties, along with 0.5-3.5 unit loss of sugar recovery in West Bengal, India. Stem borer is the most destructive pest of sugarcane in growing areas of Bangladesh. Maximum weight losses of 28.73, 18.64 and $18.01 \%$ and sucrose losses of 9.74, 11.21 and 15.93\% were estimated in Isd 16, Isd 21 and Isd 30 respectively having more than three bores in infested cane (BSFIC, 2008).

The stem borer genus Chilo contains 41 species of which Chilo tumidicostalis had been so far identified worldwide attacking many crops particularly Graminae/Poaceae family. This species and Chilo auricilius are very common and destructive in Bangladesh and India (Khanna et al., 1957; Avasthy, 1983). In addition, internode borers, Chilo sacchariphagus indicus Kapur is also a major pest of sugarcane in Peninsular India (Gupta and Avasthy, 1957). Climatic and soil conditions of both Bangladesh and India are almost similar. Besides, availability of alternate hosts during off season facilitates over-wintering of stem borer in Bangladesh. Therefore, there is a high possibility of invasion of the pest in Bangladesh. In such situation, distribution and identification of this pest at certain intervals are essential to know whether any new pest species has invaded in this country. In fact, no comprehensive work has so far been undertaken in Bangladesh to identify the different species of stem borer attacking sugarcane cultivated throughout the country since 1962. In this context, the present study was undertaken to identify and to assess the distribution of sugarcane stem borers in Bangladesh. 


\section{MATERIALS AND METHODS}

\section{Study site}

The survey was conducted at nine locations covering 12 Agro-Ecological Zones (AEZ) of Bangladesh with date of sample collection, date of placing sample in rearing box in the laboratory (Table 1). Stem borer infested sugarcanes were collected from the selected locations from August to September 2011. Nine Sugar Mills zones of Bangladesh namely Atwary, Panchagar Sugar Mills (PSM); Patuadangi farm, Thakurgaon Sugar Mills (TSM); Sultanpur farm, Setabganj Sugar Mills (STSM); Puthia, Rajshahi Sugar Mills (RJSM); Bashudebpur, Natore Sugar Mills (NTSM); BSRI farm, Pabna Sugar Mills (PBSM); Akandabaria farm, Carew \& Co. Sugar Mills; Modhukhali, Faridpur Sugar Mills (FSM) and Kaliganj, Mobarakganj Sugar Mills (MKSM) were selected for this study (Figure 1).

\section{Collection of sample}

A comprehensive survey was conducted through questionnaire by extensive visit throughout the selected locations during the cropping season of 2010-2011 and stem borer infested sugarcane fields were observed in the morning and afternoon. Adult emergence of Chilo tumidicostalis from pupae was recorded by rearing the collected specimen of 9 locations during the period from August to October 2011 and periods of stem borer infestation were recorded for nine locations of Bangladesh during the period from May to June 2011 (Figure 2 \& 3). A total of 100 infested sugarcanes (Plate 6) were checked for recording the incidence of target pest in each field of cane grower. Hundred plants were examined randomly at each sugarcane field to obtain the percent infestation of stem borer (Figure 4). At each location, three sugarcane fields were randomly selected from which specimens were collected at random from 3 different cane growers. The percent of stem borer infested sugarcane per location was calculated based on the number of total plants observed and the number of infested plants. Accordingly fifty (50) plant specimens from each location were cut and tied into bundle. The bundle of cane containing borers was brought to Entomology Laboratory of Regional Sugarcane Research Station (RSRS), Thakurgaon as well as Entomology Laboratory of Bangladesh Sugarcane Research Institute (BSRI), Ishurdi, Pabna for morphometric study. Rearing boxes were kept ready before the specimen were carried to the laboratory.

\section{Rearing of sugarcane stem borer}

Infested sugarcane collected from different locations were placed separately in netted rearing cage $(90 \mathrm{~cm} \times 60 \mathrm{~cm})$ and placed on laboratory desk. In order to culture the specimen larvae were collected by splitting borer infested stem of sugarcane. They were reared in the plastic boxes $(23.0 \mathrm{~cm}$ in dia. and $10.5 \mathrm{~cm}$ high) with pieces of sugarcane stalk as food until pupation. The pupae were kept in a Petri dish $(11.5 \mathrm{~cm}$ $\times 1.5 \mathrm{~cm}$ ) with adequate moisture provided with water-soaked filter paper in the bottom of the Petri dish until the adult emergence. Pupae were then transferred to the 
insect rearing cage $(60 \mathrm{~cm} \times 60 \mathrm{~cm} \times 90 \mathrm{~cm})$. Stock culture of stem borer was maintained at room temperature ranging from $20-30^{\circ} \mathrm{C}$. Adults emerged from full grown pupae at 7-15 days after pupation. Emerged adults were placed separately in a killing jar and their number was counted. Adult moths were then pinned, stretched and preserved for identification.

\section{Identification of sugarcane stem borer (Chilo tumidicostalis Hampson)}

The major characteristics used to identify the adult male and female of sugarcane stem borer at different stages are given in appendix I. Specimens were primarily identified with the help of taxonomic keys described by Butani (1956), Alam (1967) and Butani and Jotwani (1984) (Appendix II). The laboratory reared freshly emerged adults (moths) collected from nine locations were compared with adult characteristics

(Plate 1-6). For this purpose specific characters of each specimen were studied thoroughly and checked with the characters of the keys and all the characters were studied under binocular microscope. Larval (caterpillar) characteristics were also considered to confirm the identification.

Design and Statistical analysis: The experiment was laid out in Completely Randomized Design (CRD) with three replications. The treatment means were compared using Duncan's Multiple Range Test i.e. DMRT (Gomez and Gomez, 1984).

\section{RESULTS AND DISCUSSION}

Infested samples with larvae collected from different locations, number of pupae and number of total adult individuals emerged from the laboratory-reared sugarcane are presented in Table 2. The recently emerged adults collected from nine locations of Bangladesh belong to the genus Chilo under the family Pyralidae. In the present study through identifying characteristics keys as described by Butani (1956), it might be assumed that only Chilo tumidicostalis would be the major pest of sugarcane in all the nine locations of Bangladesh. The present results are supported by Isaac and Rao (1941) and Isaac and Venkataraman (1941) who had shown the same larval and pupal characters of stem borer.

Morphological variations were not observed among the emerged adults of both male and female. The results indicated that the morphological characteristics of larva, pupa and adults were completely comparable to that of Chilo tumidicostalis only. Thus, only one species tumidicostalis belonging to the genus Chilo under the family Pyralidae was identified. Avasthy (1983) reported that two species of Chilo (i.e., Chilo tumidicostalis and Chilo auriciliusi) had bored into sugarcane, corn and paddy. $\mathrm{He}$ observed that these species also had attacked other plants under the family Graminae/Poaceae. Kapur (1950) reported that Argyria tumidicostalis later renamed as Chilo tumidicostalis Hampson was the major borer pest of sugarcane which prevails in Bangladesh. 


\section{Number of pupae emerged}

The highest number of pupae (73) was produced from larvae of infested sugarcane collected from Patuadangi farm, Thakurgaon (Table 2). The second highest number of pupae (70) was obtained from the samples with larvae collected from Sultanpur farm, Setabganj. On the other hand, the lowest number of pupae (56) was found from the collected samples with larvae of Akandabaria farm, Carew \& Co., Dorshona. Almost similar number of pupae viz., 60, 62, 65, 67, 68 and 69 were recorded from the sugarcane samples (with larvae) of Kaliganj, BSRI farm, Pabna, Puthia, Modhukhali, Bashudebpur and Atwary, respectively.

\section{Number of Adults emerged}

From the Figure 2 the highest number of adults (50) emerged from the pupae were recorded from Patuadangi farm followed by Atwary, Sultanpur farm and Modhukhali (49). The lowest number of adults (45) emerged from the pupae of Akandabaria (Carew \& Co.) followed by BSRI farm (46). The number of adults emerged from the pupae of Puthia, Kaliganj and Bashudebpur were 47, 47 and 48, respectively.

\section{Male and female Sex Ratio}

The numbers of male and female stem borer moths emerged from the pupae of different locations are presented in Table 2. The highest number (24) of male moths emerged from the pupae of Patuadangi farm and the second highest number (22) of male moths emerged from Sultanpur farm. Number of male moths of 21 and 20 emerged from the pupae of the samples was collected from Atwary and Bashudebpur, respectively. Male moth emergence was poor from the pupae of samples collected from Modhukhali (19), Puthia (18), BSRI farm (18), Kaliganj (18) and Akandabaria farm (17). The highest number (30) of female moths emerged from the pupae of the samples from Modhukhali and the second highest number (29) from the samples of Puthia and Kaliganj followed by Atwary (28), Bashudebpur (28), BSRI farm (28) and Akandabaria farm (28). Twenty seven and twenty six female moths emerged individually from the pupae of samples collected from Sultanpur farm and Patuadangi farm. The number of female moth emergence ranged from 26-30. The lowest number (26) of female moth emerged from the pupae of samples collected from Patuadangi farm. A total of 430 moths emerged from the collected specimens of 9 different locations. Of them, 177 were males and 253 were females with a sex ratio of $1: 1.42$.

\section{Periods and rate of infestation by Chilo tumidicostalis in different locations}

From the figure 3 the initiation of infestation by stem borer was observed on 20 May in Atwary, 22 May in Patuadangi farm and 25 May in Sultanpur farm. On the other hand, stem borer infestation was found on 10 June in Rajshahi, 15 June in Natore, 18 June in Faridpur, 16 June in Pabna, 14 June in Akandabaria farm and 20 June in Mobarakganj. Panchagor, Thakurgaon and Dinajpur mills zones were the most Chilo tumidicostalis Hampson prone areas in Bangladesh. These zones have medium high 
land, sandy and sandy loam soil texture, rain fed in March, April and May but were rainy in June, July and August because these areas are closer to Dargilling and Himaloy. Sugarcane is a major crop in these areas covering 14-18 months in the field. Maize and Rice is the alternate/sequential crop which is alternate host of sugarcane stem borer. In these areas, sugarcane is planted in the early season. For this reason, stem borer infestation reached as high as 100\% in Sultanpur farm and Dinajpur (Karim and Islam, 1977).

\section{Survey record on the infestation rate of stem borer in different locations}

From the figure 4 survey report indicates that the highest rate of infestation (36\%) was observed in Atwary. Second highest rate of infestation (32\%) was recorded in Bashudebpur followed by Dinajpur (31\%), Pabna and Akandabaria farm (30\%). The lower infestation was recorded in Kaliganj (23\%), followed by Rajshahi $(28 \%)$, Thakurgaon and Faridpur (29\%). The rate of infestation of stem borer (Chilo tumidicostalis) in different locations varied from $23-36 \%$.

\section{Distribution of stem borer on host and locality}

Stem borer, Chilo tumidicostalis (Hampson) was the most abundant species which recorded 430 individuals that emerged from 590 pupae $(72.88 \%)$ reared in infested sugarcane collected from 9 different locations situated at North, South, West and Central regions of Bangladesh. These species predominantly emerged from the specimens collected from Thakurgaon but became gradually infrequent in the infested sugarcane collected from Dinajpur, Panchagor, Natore, Faridpur, Rajshahi, Pabna, Kaliganj and Dorshona (Figure 3). The present study indicated that Chilo tumidicostalis is the most damaging insect pest that bored into the sugarcane, though previous workers found other borers in addition to Chilo auricilius. Other borers which attack maize and rice choose sugarcane as alternate host. A research report was found in the web site that there were many species of Chilo so far identified worldwide which attack many crops particularly under Graminae/Poaceae family. The genus Chilo contains 41 species and of them, 8 species (i.e., Chilo agamemnon, C. auricilius, C. infuscatellus, C. orichalocociliellus, C. partellus, C. sacchariphagus, C. terrenellus and C. tumidicostalis) have damage potential in Australian cane if they invade the mainland. Additionally, two Chilo species of Australia (i.e., Chilo polychrysus and $C$. suppressalis) are major pest of rice and minor pest of sugarcane in some countries in Asia (David and Easwaramoorthy, 1990). However, Chilo suppressalis appears to be strictly a pest of rice, but there is no evidence in the literature that it can survive on sugarcane. Two other species (Chilo diffusilineus and C. zacconius) were found in Africa but might have negligible impact. The remaining 29 Chilo genera are not known to be the pests of sugarcane.

Stem borer, Chilo tumidicostalis (Hampson) is originally an Asian species. Populations in Madagascar, Malaysia, Mauritius and Reunion have probably been introduced by human in the mid 1800s (Williams, 1983). Chilo tumidicostalis is reported to feed exclusively on sugarcane, found in Bangladesh, India, Myanmar, Nepal and Thailand (David and Easwaramoorthy, 1990; Suasa-ard et al., 2000). It is known as the Bengal borer in India and used to be considered a major pest of 
sugarcane in Purnea and adjoining parts of Bhagalpur, Munger and Darbhanga districts of Bihar, but its importance seems to have declined during the 1980s (Kumar and Kalra, 1987). However, in Thailand, C. tumidicostalis used to be considered a major pest of sugarcane until the late nineties, when it unexpectedly became the most important pest of sugarcane. Severe outbreaks were reported in the provinces of $\mathrm{Sa}$ Kaew and Buri Rum in Thailand (Suasa-ard et al., 2000) and Dinajpur, Setabganj in Bangladesh (Karim and Islam, 1977) where infestation reached up to $100 \%$. However, this insect pest should have a high spread and colonization potential in sugarcane growing areas, especially in North Queensland, Taiwan and Pakistan (Sallam and Allsopp, 2002; Cheng et al., 1997; Ullah et al., 2006).

\section{CONCLUSION}

The present study indicated that Chilo tumidicostalis Hampson is the only insect pest that bored into sugarcane, though previous workers found other borers in addition to Chilo tumidicostalis. Other borers which attack sugarcane are the rice, maize borer and they choose sugarcane as alternate host. However, it is now essential to undertake more research work to find out other borers which may have been attacking sugarcane as alternate host. Another study could be conducted to identify some of the borers invading Graminae/Poaceae crops of Bangladesh.

\section{REFERENCES}

Alam, M. Z. 1967. Insect pests of sugarcane and their control. p.79-85. In: Proceedings of East Pakistan Seminar on Sugarcane Research and Development. Dacca, Bangladesh.

Avasthy, P. N. 1983. Insect Pest Management for Sugarcane in India. p. 71-77. In: M. Balasubramanian and A.R. Solayappan (ed.), Sugarcane Pest Management in India. Tamil Nadu Co-operative Sugar Federation, Madras.

BSFIC, 2008. MIS Report. Bangladesh Sugar and Food Industries Corporation. Motijheel Commercial Area, Dhaka, Bangladesh.

Butani D. K and Jotwani, M. G. 1984. Insects in Cash crop like Sugarcane. Periodical Expert Book Agency. Vivek-Vihar, Delhi, India. pp.356.

Butani, D. K. 1956. A key for the identification of sugarcane borers. Indian Journal of Entomology 18: 303-304.

Butani, D. K. 1961. Insect pests of sugarcane in Bihar. Indian Sugar 11(1): 649-654.

Cheng, W. Y., Wang, Z. T. and Chen, S. M. 1997. Occurrence of internodes and borer damaged internodes on spring cane. Report of the Taiwan Sugar Research Institute. Publication No. 158: 15-29.

Chowdhury, M. K. U. and. Vasil, I. K. 1993. Molecular analysis of plants regenerated from embryogenic cultivars of hybrid cane cultivar. Theoretical and Applied Genetics 86 (23): $181-188$.

David, H. and Easwaramoorthy, S. 1990. A study on the sugarcane internode borer, Chilo tumidicostalis Hampson. In: Proceedings of International Society of Sugar Cane Technologists 12: 1444-1453. 
Gomez, K. A. \& Gomez, A. A. 1984. Statistical Procedure for Agricultural Research. 2nd edition. John Wiley and Sons, New York. 680 pp.

Gupta, B. D. 1960. Insect pests of Sugarcane in India. VI. The stalk borer, Chilo tumidicostalis Hampson. Indian Sugar 10: 67-78.

Gupta, B. D. and Avasthy, P. N. 1957. An epidemic of stem borer, Chilo tumidicostaris Hampson. Newsletter, Indian Institute of Sugarcane Research, Lucknow. p.34.

Gupta, B. D. and Avasthy, P. N. 1960. Biology and control of stem borer, Chilo tumidicostalis Hamson. International Society of Sugar Cane Technologists 10: 886-901.

Humbert, R. P. 1968. The Growing of Sugar Cane. Elsevier publishing company, Amsterdam. $1-779$.

Isaac, P. V. and Rao, K. V. 1941. A key for the identification of the larvae of know Lepidopterous borers of sugarcane in India based on morphological characters. Indian Journal of Agricultural Sciences 11: 795-803.

Isaac, P. V. and Venkataraman, T. V. 1941. A key for the identification of the pupae of know Lepidopterous borers of sugarcane in India based on morphological characters. Indian Journal of Agricultural Sciences 11: 804-815.

Kapur, A. P. 1950. The identity of some Crambinae associated with sugarcane in India and certain species related to them (Lepidoptera : Pyralidae). Transactions of the Royal Entomological Society, London. 101:38-43.

Karim, M. A. and Islam, M. N. 1977. Stem borer of sugarcane in Bangladesh. In Proc. The $22^{\text {nd }}$ Annual Scientific Conference, Bangladesh Association for Advancement of Science pp 29-30.

Khanna, K. L., Nigam, L. N. and Puri, V. D. 1957. Stem borer, Chilo tumidicostalis Hampson, a serious pest of sugarcane in Bihar. In: Proceedings of the Indian Academy of Science (B) 46: 75-95.

Kumar, S. and Kalra, A. N. 1987. Attack of stem borer, Chilo tumidicostalis Hampson as a cane borer in Rajasthan. Indian Sugarcane Journal 9: 154-156.

Sallam, M.N. 2006. A Review of sugarcane stem borers and their natural enemies in Asia and Indian Ocean Islands: an Australian perspective. Annales de la Société entomologique de France, 42 (3-4): 263-283

Sallam, M.N. and Allsopp, P.G. 2002. Preparing for borer incursion into Australia. Australian Sugarcane 5(6): 5-7.

Suasa-ard, W., Wiwat-suasa-ard and Allsopp, P.G. 2000. Chilo tumidicostalis Hamson (Lepidoptera: Pyralidae) and its natural enemies in Thailand. pp. 10-16. In: Proceedings of the $4^{\text {th }}$ Sugarcane-Entomology- Workshop, International society of sugarcane Technologists, Sugarcane pest Management in the New Millennium., 7-10 February, 2000. Khon Kaeno, Thailand.

Ullah, M., Butt, B. U. and Shah, M. 2006. Assessment of cane and internode damage in millable cane by sugarcane pest complex. Sarhad Journal of Agriculture 22(2): 202207.

Williams, J. R. 1983. The sugarcane stem borer, Chilo tumidicostalis Hamson in Mauritius. Revue Agricole et Sucrière de l'Île Maurice 62: 5-23.

Williams, J. R., Metcalfe, J. R., Mongomery, R. W. and Mathes, R. 1969. Pests of Sugarcane Elsevier, Amsterdam. 
Table 1. Name of locations, date of collection and placement of sugarcane samples in rearing boxes in the Entomology Laboratories

\begin{tabular}{|c|c|c|c|}
\hline Selected locations & Date of sample collection & $\begin{array}{c}\text { Date of sample } \\
\text { placement in rearing box }\end{array}$ & Laboratory \\
\hline Atwary, Panchagor Sugar Mills (PSM) & 24 August 2011 & 25 August 2011 & RSRS, Thakurgaon \\
\hline Patuadangi farm, Thakurgaon Sugar Mills (TSM) & 26 August 2011 & 27 August 2011 & RSRS, Thakurgaon \\
\hline Sultanpur farm, Setabganj Sugar Mills (STSM) & 25 August 2011 & 26 August 2011 & RSRS, Thakurgaon \\
\hline Puthia, Rajshahi Sugar Mills (RJSM) & 10 September 2011 & 11 September 2011 & BSRI, Ishurdi, Pabna \\
\hline Bashudebpur, Natore Sugar Mills (NTSM) & 11 September 2011 & 12 September 2011 & BSRI, Ishurdi, Pabna \\
\hline Modhukhali, Faridpur Sugar Mills (FSM) & 12 September 2011 & 13 September 2011 & BSRI, Ishurdi, Pabna \\
\hline BSRI farm, Pabna Sugar Mills (PBSM) & 17 September 2011 & 18 September 2011 & BSRI, Ishurdi, Pabna \\
\hline Akandabaria, Carew \& Co. Sugar Mills (Carew \& Co.) & 18 September 2011 & 20 September 2011 & BSRI, Ishurdi, Pabna \\
\hline Kaliganj, Mobarakganj Sugar Mills (MKSM) & 19 September 2011 & 21 September 2011 & BSRI, Ishurdi, Pabna \\
\hline
\end{tabular}

Table 2. The number of stem borer moth emerged from infested sugarcane samples from Nine sugar Mills of Bangladesh

\begin{tabular}{|c|c|c|c|c|c|}
\hline \multirow[t]{2}{*}{ Selected locations } & \multirow{2}{*}{$\begin{array}{l}\text { Number of } \\
\text { observed } \\
\text { samples }\end{array}$} & \multirow{2}{*}{$\begin{array}{l}\text { Number of } \\
\text { pupae } \\
\text { produced }\end{array}$} & \multirow{2}{*}{$\begin{array}{l}\text { Number of } \\
\text { adult } \\
\text { emerged }\end{array}$} & \multicolumn{2}{|c|}{$\begin{array}{c}\delta \text { and } q \text { ratio of } \\
\text { Chilo tumidicostalis }\end{array}$} \\
\hline & & & & $\hat{0}$ & P \\
\hline Atwary, Panchagor Sugar Mills (PSM) & 100 & 69 & 49 & $21(30.43)$ & $28(40.58)$ \\
\hline Patuadangi farm, Thakurgaon Sugar Mills (TSM) & 100 & 73 & 50 & $24(32.88)$ & $26(35.62)$ \\
\hline Sultanpur farm, Setabganj Sugar Mills (STSM) & 100 & 70 & 49 & $22(31.43)$ & $27(38.57)$ \\
\hline Puthia, Rajshahi Sugar Mills (RJSM) & 100 & 65 & 47 & $18(27.69)$ & $29(44.62)$ \\
\hline Bashudebpur, Natore Sugar Mills (NTSM) & 100 & 68 & 48 & $20(29.41)$ & $28(41.18)$ \\
\hline Modhukhali, Faridpur Sugar Mills (FSM) & 100 & 67 & 49 & $19(28.36)$ & $30(44.78)$ \\
\hline BSRI farm, Pabna Sugar Mills (PBSM) & 100 & 62 & 46 & $18(30.00)$ & $28(46.67)$ \\
\hline $\begin{array}{l}\text { Akandabaria, Carew \& Co. Sugar Mills (Carew \& } \\
\text { Co.) }\end{array}$ & 100 & 56 & 45 & $17(30.36)$ & $28(50.00)$ \\
\hline Kaliganj, Mobarakganj Sugar Mills (MKSM) & 100 & 60 & 47 & $18(29.03)$ & $29(46.77)$ \\
\hline Total & 900 & 590 & 430 & 177 & 253 \\
\hline
\end{tabular}

Male $:$ Female $=1: 1.42$ 


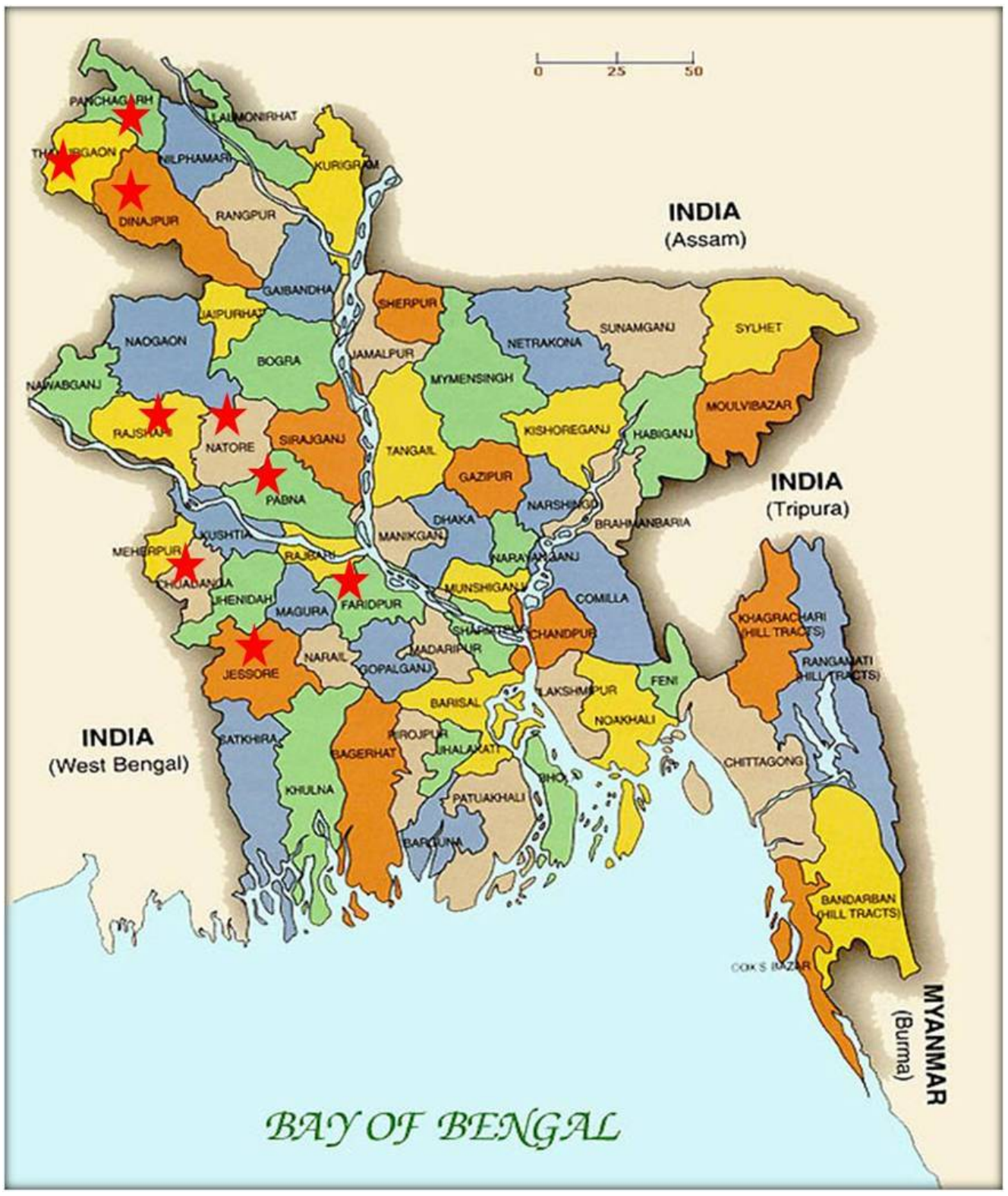

Figure 1. Stars in the map showing nine selected locations under 12 Agro-Ecological Zones (AEZ) of Bangladesh 


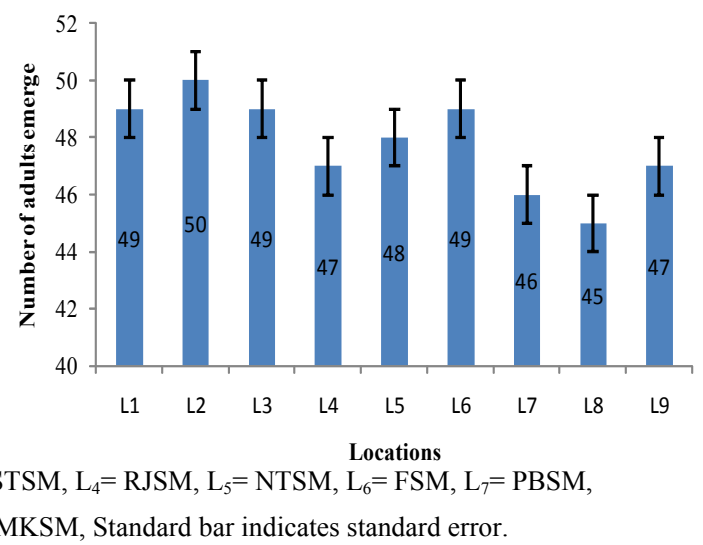

$\mathrm{L}_{1}=\mathrm{PSM}, \mathrm{L}_{2}=\mathrm{TSM}, \mathrm{L}_{3}=\mathrm{STSM}, \mathrm{L}_{4}=\mathrm{RJSM}, \mathrm{L}_{2}=\mathrm{N}$.
$\mathrm{L}_{8}=$ arew \& Co. and $\mathrm{L}_{9}=$ MKSM, Standard bar indicates standard error.

Figure 2. Adult emergence from the pupae of Chilo tumidicostalis reared from the collected specimens of nine locations of Bangladesh during August-October, 2011

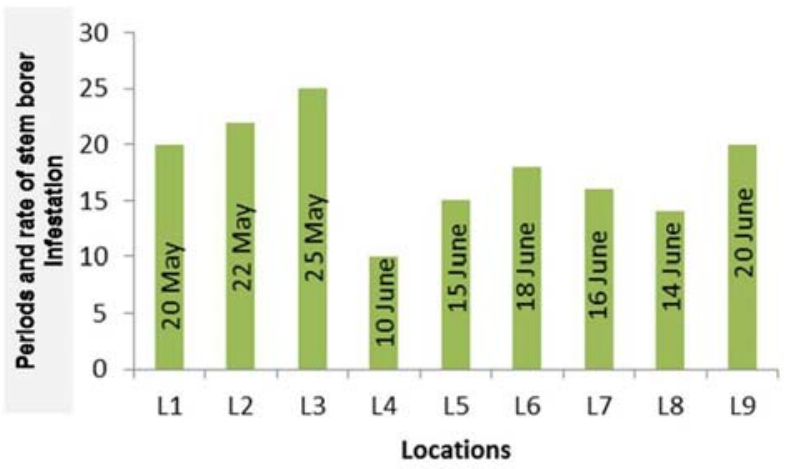

$\mathrm{L}_{1}=$ PSM, $\mathrm{L}_{2}=$ TSM, $\mathrm{L}_{3}=$ STSM, $\mathrm{L}_{4}=$ RJSM, $\mathrm{L}_{5}=$ NTSM, $\mathrm{L}_{6}=$ FSM, $\mathrm{L}_{7}=$ PBSM,

$\mathrm{L}_{8}=$ Carew \& Co. and $\mathrm{L}_{9}=$ MKSM

Figure 3. Periods and rate of infestation by stem borer in nine locations of Bangladesh during May-June, $2011(P<0.01)$.

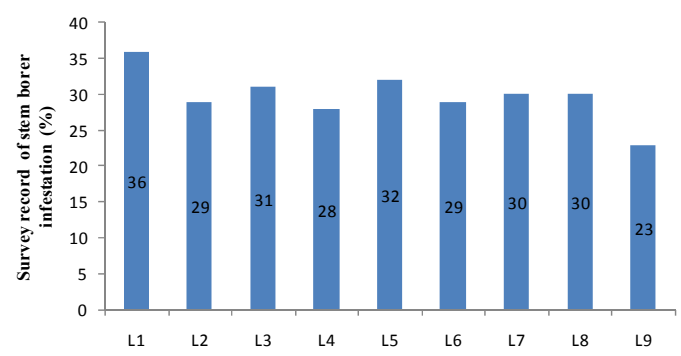

$\mathrm{L}_{1}=$ PSM, $\mathrm{L}_{2}=$ TSM, $\mathrm{L}_{3}=$ STSM, $\mathrm{L}_{4}=$ RJSM, $\mathrm{L}_{5}=$ NTSM, $\mathrm{L}_{6}=\mathrm{FSM}, \mathrm{L}_{7}=$ PBSM,

$\mathrm{L}_{8}=$ Carew \& Co. and $\mathrm{L}_{9}=$ MKSM

Figure 4. Mean percent infestation by stem borer in nine locations of Bangladesh during the cropping season of 2010-2011 $(P<0.01)$. 


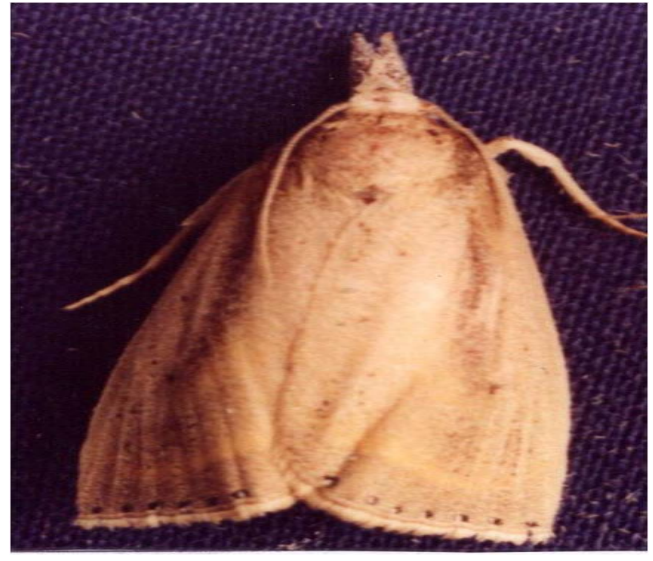

Plate 1. Seven spots present in terminal side of adult Chilo tumidicostalis

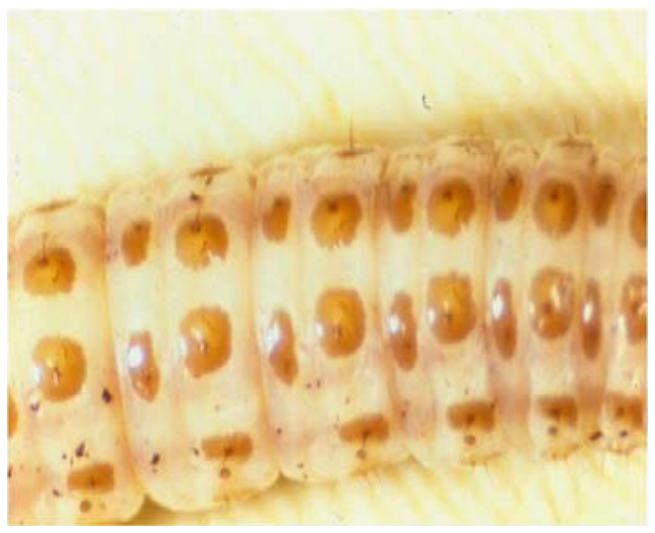

Plate 3. Four pinkish brown stripes (mature larva)

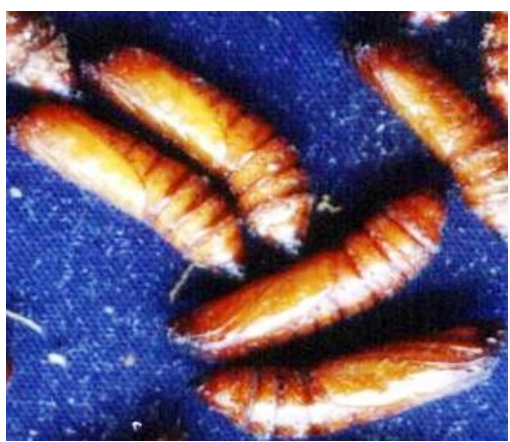

Plate 5. The $5^{\text {th }}, 6^{\text {th }}$, and $7^{\text {th }}$ abdominal segments chitinized and branched spines

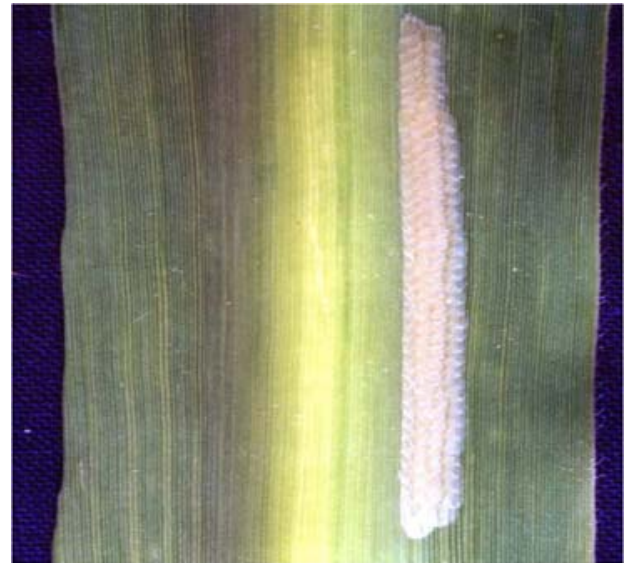

Plate 2. Two - five tier eggs of Chilo tumidicostalis

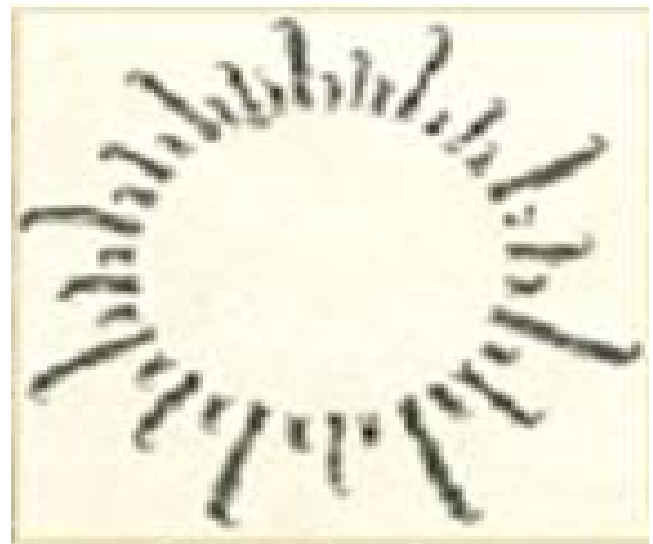

Plate 4. Complete crochets on planta of prolegs in triple series

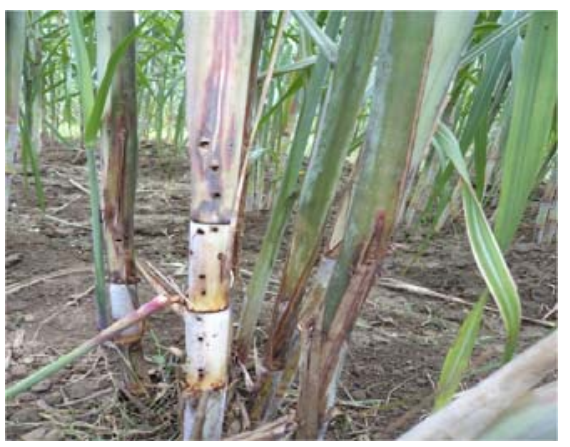

Plate 6 . Entry wholes by stem borer in sugarcane 


\section{Appendix I. Characteristics of egg, larva, pupa and adult of sugarcane stem borer}

\begin{tabular}{|c|c|c|c|c|c|}
\hline $\begin{array}{l}\text { Behaviour of egg } \\
\text { laying }\end{array}$ & $\begin{array}{l}\text { Time of } \\
\text { egg laying }\end{array}$ & $\begin{array}{l}\text { Oviposition } \\
\text { period } \\
\text { (day) }\end{array}$ & $\begin{array}{l}\text { Number of } \\
\text { eggs in } \\
\text { total life }\end{array}$ & Egg size & Egg colour \\
\hline $\begin{array}{l}\text { On Ist } 2^{\text {nd }} \text { and } 3^{\text {rd }} \\
\text { top leaves, leaf } \\
\text { sheath in rows of } \\
2-5 \text { tiers (Plate } \\
\text { 2). }\end{array}$ & Evening & 4 & $\begin{array}{l}500-800 \\
\text { and eggs } \\
\text { are } \\
\text { uncovered }\end{array}$ & $\begin{array}{l}\text { Length: } 1.2 \mathrm{~mm} \\
\text { Width: } 0.8 \mathrm{~mm}\end{array}$ & $\begin{array}{l}\text { Dirty white with } \\
\text { light greenish } \\
\text { tinge but reddish } \\
\text { at hatching }\end{array}$ \\
\hline
\end{tabular}

2).

\section{Larval stage}

\begin{tabular}{|c|c|c|c|c|c|}
\hline $\begin{array}{l}\text { Crochet on the } \\
\text { prolegs }\end{array}$ & $\begin{array}{l}\text { Average } \\
\text { larval } \\
\text { period } \\
\text { (days) }\end{array}$ & $\begin{array}{l}\text { Number } \\
\text { and colour } \\
\text { of stripes }\end{array}$ & $\begin{array}{l}\text { Number of } \\
\text { instar }\end{array}$ & $\begin{array}{l}\text { Average larvae } \\
\text { size }\end{array}$ & Larval colour \\
\hline $\begin{array}{l}\text { Complete } \\
\text { crochets on } \\
\text { planta of prologs } \\
\text { are arranged in } \\
\text { triple series } \\
\text { (triordinal) (Plate } \\
\text { 4). }\end{array}$ & $27-70$ & $\begin{array}{l}\text { Four } \\
\text { pinkish } \\
\text { brown } \\
\text { stripes are } \\
\text { alike (Plate } \\
\text { 3). }\end{array}$ & 5 & $\begin{array}{l}\text { Young: } 1-3 \mathrm{~mm} \\
\text { Mature: } 3 \mathrm{~mm}\end{array}$ & $\begin{array}{l}\text { White with } \\
\text { black/orange } \\
\text { head, later stage } \\
\text { creamy. Dark } \\
\text { brown spots } \\
\text { bearing hairs on } \\
\text { body segments. }\end{array}$ \\
\hline
\end{tabular}

\begin{tabular}{|c|c|c|c|c|c|c|c|}
\hline \multicolumn{8}{|l|}{ Pupal stage } \\
\hline \multicolumn{3}{|c|}{ Characteristics } & \multicolumn{2}{|c|}{$\begin{array}{l}\text { Average pupal } \\
\text { period (days) }\end{array}$} & \multicolumn{2}{|c|}{ Average pupal size } & Pupal colour \\
\hline \multicolumn{3}{|c|}{$\begin{array}{l}\text { 1. Front of fronto-clypeal region } \\
\text { extends upward forming hard ridge } \\
\text { like projections. } \\
\text { 2. The } 5^{\text {th }}, 6^{\text {th }} \text { and } 7^{\text {th }} \text { abdominal } \\
\text { segments with prominent hard and } \\
\text { branched spines (Plate } 5 \text { ). }\end{array}$} & \multicolumn{2}{|c|}{$\begin{array}{l}7-15 \text { up to } 22 \text { day } \\
\text { in cool weather }\end{array}$} & \multicolumn{2}{|c|}{ Long: $16-20 \mathrm{~mm}$} & Brown \\
\hline \multicolumn{8}{|l|}{ Adult stage } \\
\hline \multirow{2}{*}{$\begin{array}{l}\text { Behaviour } \\
\text { of egg } \\
\text { laying }\end{array}$} & \multirow{2}{*}{$\begin{array}{l}\text { Adult } \\
\text { longevity } \\
\text { (day) }\end{array}$} & \multirow{2}{*}{\multicolumn{2}{|c|}{ Adult colour }} & \multicolumn{2}{|c|}{ Width at wingspan } & \multicolumn{2}{|c|}{ Difference at $\phi$ and $\hat{\partial}$} \\
\hline & & & & † $(\mathrm{mm})$ & $\widehat{\delta}(\mathrm{mm})$ & q & $\hat{\sigma}$ \\
\hline \multicolumn{2}{|l|}{ Nocturnal } & \multicolumn{2}{|c|}{$\begin{array}{l}\text { Yellowish } \\
\text { with narrow } \\
\text { brown lines on } \\
\text { forewing } \\
\text { (Plate 1). }\end{array}$} & $25-40$ & $18-30$ & $\begin{array}{l}\text { Anal part } \\
\text { U-shaped }\end{array}$ & $\begin{array}{l}\text { Thick hair on } \\
\text { anal part }\end{array}$ \\
\hline
\end{tabular}




\section{Appendix II. Standard Key for Identification of sugarcane borer pests}

\begin{tabular}{|c|c|c|c|}
\hline Particulars & $\begin{array}{l}\text { Stalk borer } \\
\text { (Chilo auricilius) }\end{array}$ & $\begin{array}{l}\text { Plassey borer } \\
\text { (Chilo tumidicostalis) }\end{array}$ & $\begin{array}{l}\text { Internode borer } \\
\text { (Chilo sachariphagous } \\
\text { indicus) }\end{array}$ \\
\hline $\begin{array}{l}\text { Number of } \\
\text { stripes }\end{array}$ & Five: Almost alike & Four: Almost alike & Four: Almost alike \\
\hline $\begin{array}{l}\text { Colour of } \\
\text { stripes }\end{array}$ & Violet & Pinkish brown & Violet \\
\hline $\begin{array}{l}\text { Colour of } \\
\text { tubercles }\end{array}$ & Grey & Grey & Jet black \\
\hline $\begin{array}{l}\text { Crochet on } \\
\text { the prolegs }\end{array}$ & $\begin{array}{l}\text { Complete crochets } \\
\text { with biordinal spines } \\
\text { in the prolegs }\end{array}$ & $\begin{array}{l}\text { Complete crochets with triordinal } \\
\text { spines in the prologs }\end{array}$ & $\begin{array}{l}\text { Complete crochets with } \\
\text { triordinal spines in the } \\
\text { prolegs }\end{array}$ \\
\hline Egg & $\begin{array}{l}\text { Egg laid in egg mass } \\
\text { of } 2-5 . \text { Total of } 47- \\
146 \text { eggs. }\end{array}$ & $\begin{array}{l}\text { Egg lay in } 4-5 \text { tiers. Total of 500- } \\
800 \text { eggs. Eggs are uncovered. }\end{array}$ & $\begin{array}{l}\text { Egg laid cluster in } 2-3 \\
\text { parallel rows. Total eggs } \\
\text { of few to } 414 \text {. }\end{array}$ \\
\hline larvae & Head black & Black/ orange colour head & Head black \\
\hline Adult & $\begin{array}{l}\text { Forewing straw } \\
\text { colour with golden } \\
\text { spot. Hindwing straw } \\
\text { colour with silvery } \\
\text { fringe }\end{array}$ & $\begin{array}{l}\text { Forewing dark brown scales. } \\
\text { Terminal series of black spots } \\
\text { present. Hindwing light brown } \\
\text { scales. Seven spots present in } \\
\text { terminal side. }\end{array}$ & $\begin{array}{l}\text { Straw colour with slightly } \\
\text { dark spot on forewing. }\end{array}$ \\
\hline
\end{tabular}

According to Butani (1956) 